\title{
Influence of different protected cultivation structures on performance of cucumber (Cucumis sativus L.) in Indian hot arid region
}

\section{P.S. KHAPTE ${ }^{2 *}$, H.M. MEENA ${ }^{1}$, PRADEEP KUMAR ${ }^{1}$, UDAY BURMAN ${ }^{1}$, ANURAG SAXENA ${ }^{1}$ and PRAVEEN KUMAR ${ }^{1}$}

\author{
${ }^{1} I C A R-C A Z R I$, Jodhpur, Rajasthan, India \\ ${ }^{2}$ ICAR-NIASM, Baramati, Maharashtra, India \\ *Corresponding author: khaptepratap@gmail.com
}

\begin{abstract}
The performance of gynoecious cucumber (cv. Terminator) was evaluated under three protected structures viz., naturally ventilated polyhouse (NVP), insect proof net house (INH) and shade net house $(\mathrm{SNH})$ at Jodhpur, Rajasthan in hot arid region of India. The photosynthetically active radiation (PAR) inside these structures during cropping period ranged from $154-842 \mu \mathrm{mol} \mathrm{m} \mathrm{m}^{-2} \mathrm{~s}^{-1}$ which was much lower than the outside. Among structures, air temperature was $1.2^{\circ} \mathrm{C}$ and $0.7^{\circ} \mathrm{C}$ lower while relative humidity (RH) was 17 and 4 per cent higher in NVP and SNH respectively as compared to INH. Relatively low air as well as soil temperature, coupled with high $\mathrm{RH}$ and optimal radiation in NVP led to better plant growth and physiological activity which resulted in 42 and 142per cent higher yield than INH and $\mathrm{SNH}$, respectively. Hence, it can be recommended that NVP is the best low-tech protected structure which modifies the microclimate favouring successful cultivation of greenhouse cucumber in Indian hot arid regions.
\end{abstract}

Key words: Protected structures, microclimate, cucumber, hot arid region

Protected cultivation in the arid western plains of India is picking pace because the open field cultivation in this region is highly vulnerable to biotic and abiotic factors (Kumar et al. 2019). There are different types of protected structures that vary from high-tech active climate controlled to low-tech with passive climate control structures. The resource poor farmers need lowtech protected structures to cultivate high value crops in this region for enhanced economic security (Shukla et al. 2016). In low-tech protected structures which do not possess artificial means of climate control, the cladding material used is one of the means to affect the microclimatic variables inside the structures. The microclimate of a polyhouse depends on the type of cladding material, structure configuration, crop and climatic condition of the site (Mahmood et al., 2018).

Cucumber (gynoecious and parthenocarpic) is predominantly grown vegetable crop under common protected structure (i.e., polyhouse and nethouse) in arid and semi-arid regions of the country. In spite of the influence of agronomical variables, the performance of crops varies in different protected structures. In fact, in low-tech protected structures, inside microclimatic parameters are greatly influenced by structural components, especially the cladding material. In this regard, an attempt has been made to study the effect of modified micro-climatic variables occurring inside common low-tech protected structures and their effect on growth, physiology and production of cucumber crop in the hot-arid region of India.

\section{MATERIALS AND METHODS}

\section{Experiment site}

The present study was carried out at an experimental research farm of the ICAR-CAZRI, Jodhpur, Rajasthan. The climate of the region is hot arid, characterized by high diurnal and seasonal temperature variations associated with strong winds. The microclimate that prevailed in ambient condition during the cucumber growing period has been shown in Table 1.

\section{Experimental structures}

The experiment was conducted in three different types of protected cultivation structures namely, naturally ventilated polyhouse (NVP), insect proof net house 
(INH) and shade net house (SNH). All the structures were oriented in North-South direction of 16 meter in length and 8 meter in width having $128 \mathrm{~m}^{2}$ surface area. The ridge and side height were 4 meters and 2.5 meters, respectively. The details of structures and their cladding material were as follows:

1. Naturally ventilated polyhouse: The polyhouse was cladded with 200-micron UV stabilized 5-layer high density polyethylene sheet with 89 per cent light transmission. The side ventilation was 20 per cent and while the top ventilation was 10 per cent of the surface area. The ventilation area was covered with 40 mesh insect proof net. A mobile white shade net of 50 per cent shading factor was placed inside the structure above 2.5 meter ground level.

2. Insect proof net house: This structure was cladded with 40 mesh pearl white colour insect proof net and mobile white shade net of 50per cent shading factor was placed inside the structure above 2.5-meter ground level.

3. Shade net house: Green shade net of 50per cent shading factor was used as cladding material.

\section{Microclimatic measurement}

During daytime, different microclimatic parameters were measured at hourly intervals inside the protected structures. These parameters were measured at vegetative stage (30 DAT/September), reproductive stage (60 DAT/October) and maturity stage (90 DAT/ November). The PAR was recorded with line quantum sensor (Apogee, MQ-301, Series\#1178), net radiation with Net radiometer (Middleton S. No. 1238), air temperature and relative humidity measured with Assmman psychrometer (Hisamatsu make, Model MR-58) and soil temperature with digital thermometer (Century Instruments (P) Ltd,Model CT -802, S.No. 754) at $10 \mathrm{~cm}$ depth.

\section{Agronomic practice}

Thirteen days old seedlings of gynoecious cucumber (cv. Terminator, Yuksel Tohum, Turkey) were transplanted in soil on raised beds on $20^{\text {th }}$ August, 2018 in all the structures in a paired row of $50 \times 50 \mathrm{~cm}$ spacing accommodating 3.0 plants $\mathrm{m}^{-2}$. At the time of land preparation, $25 \mathrm{t} \mathrm{ha}^{-1}$ compost and $1.0 \mathrm{t} \mathrm{ha}^{-1}$ neem cake was mixed by tilling in the top $(15 \mathrm{~cm})$ soil. The fertilizers were given through fertigation as per Kumar et al. (2019). The crop management practices including irrigation, training and pruning, and crop protection were similarly followed in all the structures.

\section{Growth and yield parameters}

Plant growth and yield parameters were measured on five randomly selected plants in each replication. At final harvest, the aerial plant parts were separated and their dry weight (DW) was determined after oven-drying at $65^{\circ} \mathrm{C}$ until constant weight was obtained. Leaf area was recorded using leaf area meter (LI-3100C, LI-COR, Inc., USA). All harvested fruits of each plant were counted and weighed to determine the number of fruits per plant, average fruit weight (g) and yield per plant (kg).

\section{Physio-biochemcial parameters}

At active growth period during reproductive stage $\mathrm{Fv} / \mathrm{Fm}$ was measured with chlorophyll fluorescence meter (OS-30P, Opti-Sciences, Inc., USA.) and net photosynthesis rate was measured with portable photosynthesis system (CIRAS-2, PP Systems, Inc., USA.) while chlorophyll concentration in fresh leaf tissues was estimated following Arnon, (1949).

The mean data of each replication were subjected to analysis of variance using statistical software INDOSTAT version 8.2. The differences between mean data were tested by analysis of variance to assess differences group means. $\mathrm{P}$ values $<0.5$ were considered significant.

\section{RESULTS AND DISCUSSION}

\section{Photosynthetically active radiation (PAR)}

The average PAR in the three structures ranged from 154-842 $\mu \mathrm{mol} \mathrm{m} \mathrm{m}^{-2} \mathrm{~s}^{-1}$ during the cucumber growing period compared to $130-1847 \mu \mathrm{mol} \mathrm{m} \mathrm{m}^{-2} \mathrm{~s}^{-1}$ in open conditions (Fig. 1 and Table 1). Rajasekharan and Nandini (2015) also reported that availability of PAR $\left(\mu \mathrm{mol} \mathrm{m} \mathrm{m}^{-2} \mathrm{~s}^{-1}\right)$ during cucumber crop was reduced 48 per cent inside the polyhouse $550.97\left(\mu \mathrm{mol} \mathrm{m} \mathrm{m}^{-2} \mathrm{~s}^{-1}\right)$ when compared to full sunlight $1063\left(\mu \mathrm{mol} \mathrm{m}{ }^{-2} \mathrm{~s}^{-1}\right)$ under open condition. Among the structures the least variation in PAR throughout the day and also across stages was noted in NVP which likely helped to relatively better maintain physiological functioning. Contrary to this, the high level of PAR (both mean and its range) in INH, especially in mid-day hours 
Table 1: Microclimatic variables in open conditions at various growth stages

\begin{tabular}{llll}
\hline Parameters & Vegetative & Reproductive & Maturity \\
\hline PAR $\left(\mu \mathrm{mol} \mathrm{m} \mathrm{m}^{-2} \mathrm{~s}^{-1}\right.$ & $130-1847(1155)$ & $199-1612(1015)$ & $258-1394(849)$ \\
Net radiation $\left(\mathrm{Wm}^{-2}\right)$ & $47-382(218)$ & $30-316(194)$ & $12-283(164)$ \\
Air temperature $\left({ }^{\circ} \mathrm{C}\right)$ & $29-37(34)$ & $26-37(34)$ & $24-34(32)$ \\
Relative humidity $(\%)$ & $23-55(36)$ & $9-34(16)$ & $18-41(23)$ \\
Soil temperature $\left({ }^{\circ} \mathrm{C}\right)$ & $25-37(32)$ & $23-36(32)$ & $22-31(27)$ \\
\hline
\end{tabular}

Mean values are within parentheses

Table 2: Growth performance of cucumber $\left(\right.$ Plant $\left.^{-1}\right)$ in protected structures

\begin{tabular}{lccccc}
\hline \multicolumn{1}{c}{ Treatment } & Dry biomass $(\mathrm{g})$ & Vine length $(\mathrm{m})$ & Leaf area $\left(\mathrm{m}^{2}\right)$ & Node number & Stem girth $(\mathrm{mm})$ \\
\hline NVP & 87.37 & 3.45 & 1.75 & 45.33 & 13.05 \\
INH & 77.55 & 2.24 & 1.24 & 40.31 & 11.66 \\
SNH & 77.71 & 2.99 & 1.63 & 40.00 & 9.517 \\
\hline C.D. & 2.10 & 0.25 & 0.05 & 1.55 & 0.64 \\
\hline
\end{tabular}

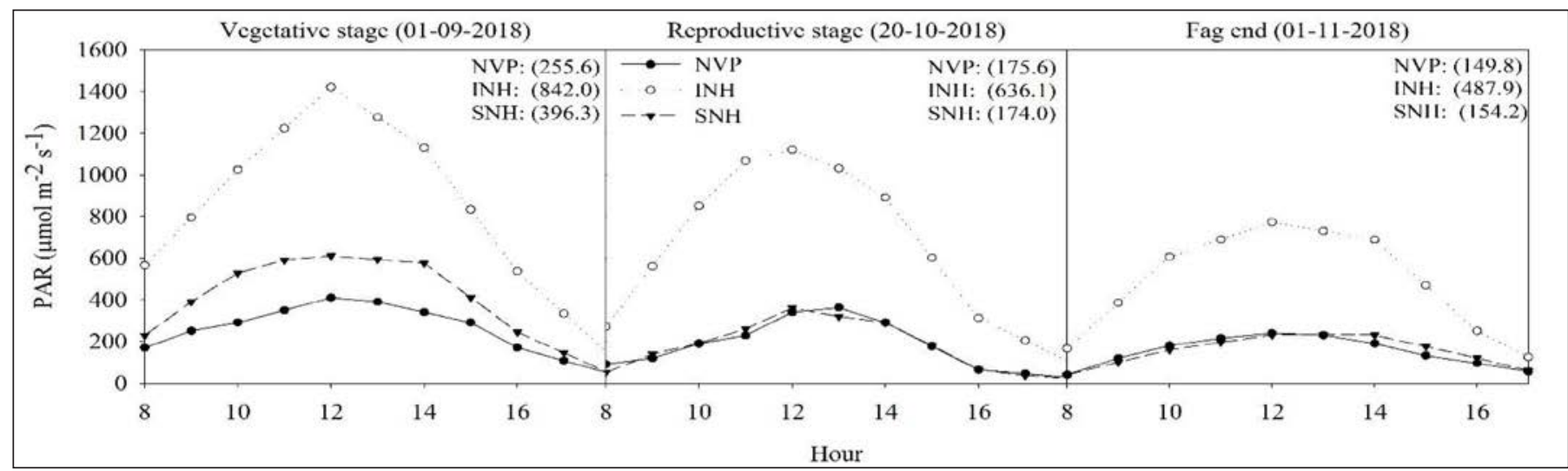

Fig. 1: PAR at hourly interval under protected structures at different growth stages

might have adversely affected plant metabolisms. The PAR in INH was higher than in other structures throughout the growing period which seems to be detrimental for optimum growth due to photo inhibition of cucumber. The reduction in PAR with the advancement of the crop stage was likely due to transition of season from rainy to winter which also influenced the microclimatic parameters that subsequently influenced crop growth. Similarly, Sudhakar et al. (2013) has reported that the amount of PAR energy depends upon location, time of the year and atmospheric conditions.

\section{Net radiation}

In general, the irradiance of solar radiation as well as net radiation remains fairly high during the period of study (post rain to autumn). Excessive radiation beyond a certain limit is detrimental to the plants as it adversely affects plant physiological functioning. The average availability of net radiation was found in optimal range in NVP at first two stages as per the observation of Singh et al. (2017), they reported $100-169 \mathrm{Wm}^{-2}$ solar radiation in naturally ventilated greenhouse for optimal plant growth and development of cucumber (Fig. 2). At maturity stage, however, net radiation was sub-optimal from September to November, this reduction was in fact due to onset of winter. In NVP the net radiation was consistent and recorded least variation throughout the day while in net houses (INH and SNH) high variations were observed. The net radiation was maximum in INH and was reduced to 34 per cent and 25 per cent at vegetative stage in NVP and SNH, respectively. While at reproductive stage corresponding reduction was found almost 50 per cent in NVP and SNH. Our observations are in line with several 

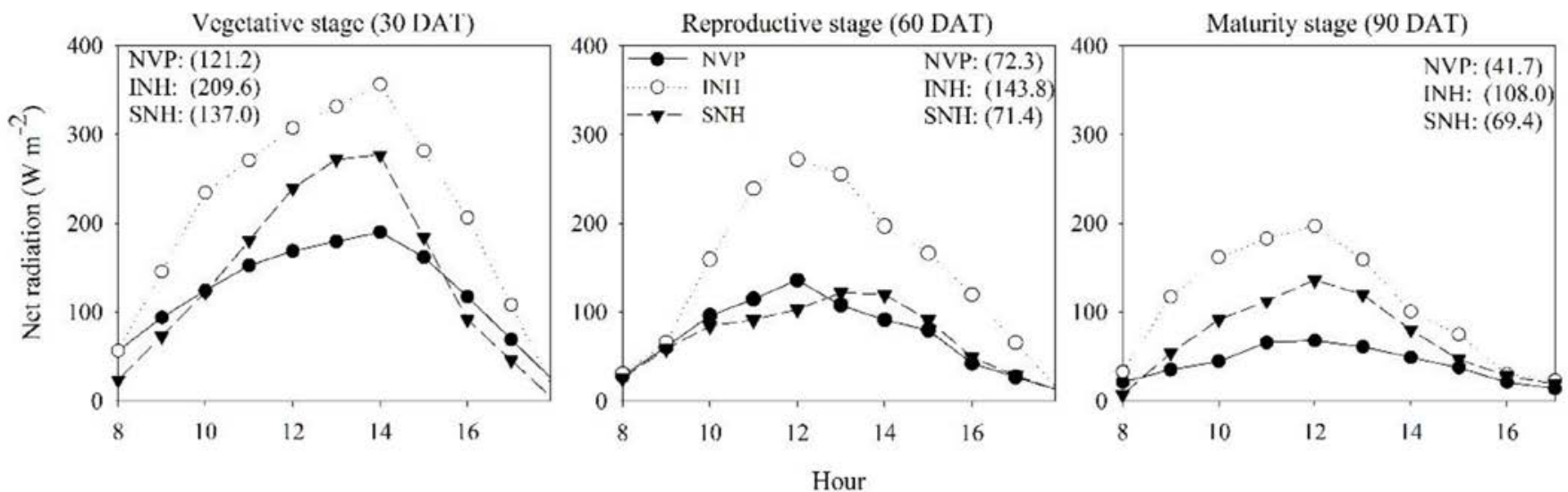

Fig. 2: Net radiation at hourly interval under protected structures at different growth stages

Table 3: Chlorophyll, Fv/Fm, net photosynthesis and fruit weight and yield parameters of cucumber in protected structures

\begin{tabular}{lcccccc}
\hline Treatment & $\begin{array}{c}\text { Chlorophyll } \\
\text { content }\left(\mu \mathrm{gl}^{-1}\right)\end{array}$ & Fv/Fm & $\begin{array}{c}\text { Pn } \\
\left(\mu \mathrm{mol} \mathrm{m}^{-2} \mathrm{~s}^{-1}\right)\end{array}$ & $\begin{array}{c}\text { No. of fruits } \\
\text { per plant }\end{array}$ & Fruit weight (g) & $\begin{array}{c}\text { Yield (kg } \\
\text { Plant }\end{array}$ \\
\hline NVP & 12.00 & 0.71 & 8.73 & 24.50 & 169.22 & 4.14 \\
INH & 9.77 & 0.66 & 7.03 & 19.66 & 148.39 & 2.91 \\
SNH & 12.44 & 0.68 & 5.45 & 12.51 & 136.73 & 1.71 \\
C.D. & 1.79 & 0.03 & 0.14 & 1.69 & 19.76 & 0.35 \\
\hline
\end{tabular}
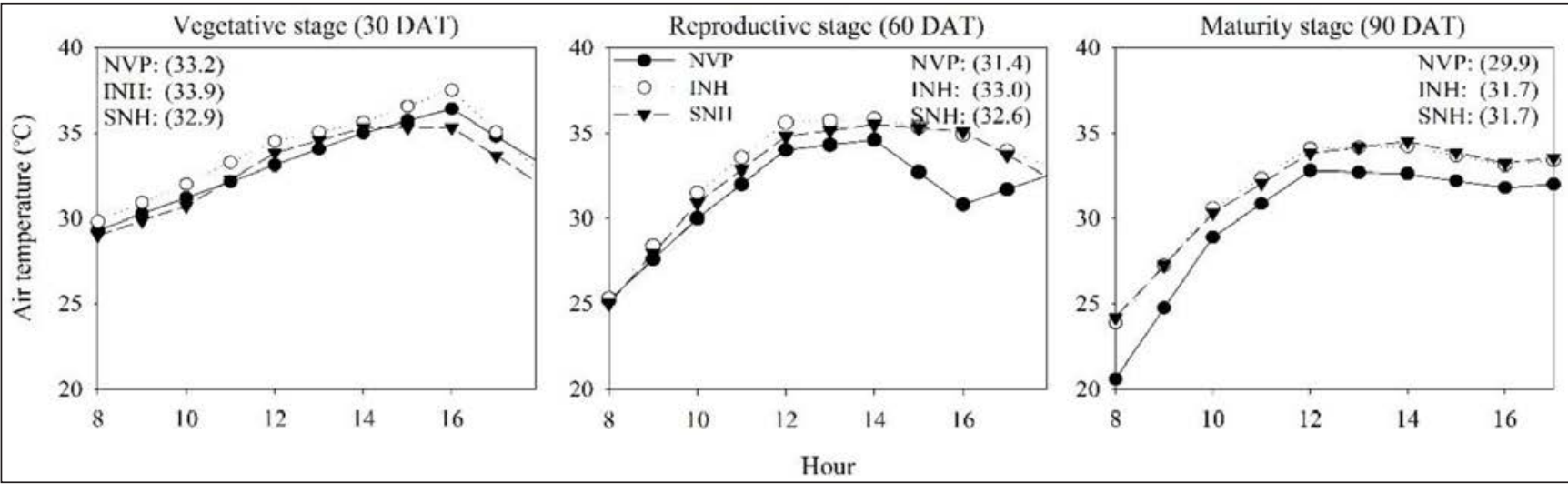

Fig. 3: Air temp at hourly interval under protected structures at different growth stages

reports that also highlighted consistently lower light intensity inside the greenhouse such as reported by Job (2017) to a tune of 30-50 per cent as compared to open.

\section{Air temperature and relative humidity}

The average temperature within the structures, at all growth stages, was less compared to open conditions (Table 1 and Fig, 3). Among the structures, NVP recorded lower average temperature while higher was noted in INH across all the stages of crop growth. Therefore, temperature was consistently lower in NVP as compared to structures as well as open field conditions. The significant reduction in air temperature attributed to different types of shading nets has also been reported in a greenhouse sweet pepper (Samanta and Hazra, 2019). The low temperature in NVP was also attributed to low radiation levels because the polyethylene film had 89 per cent light transmission and also due to use of mobile shade net inside the structure. Other structures too had cladding material with 50 per cent shading factor but there was scope of some amount of air flow.

In this study too, the relative humidity was higher inside the structures as compared to that of ambient 

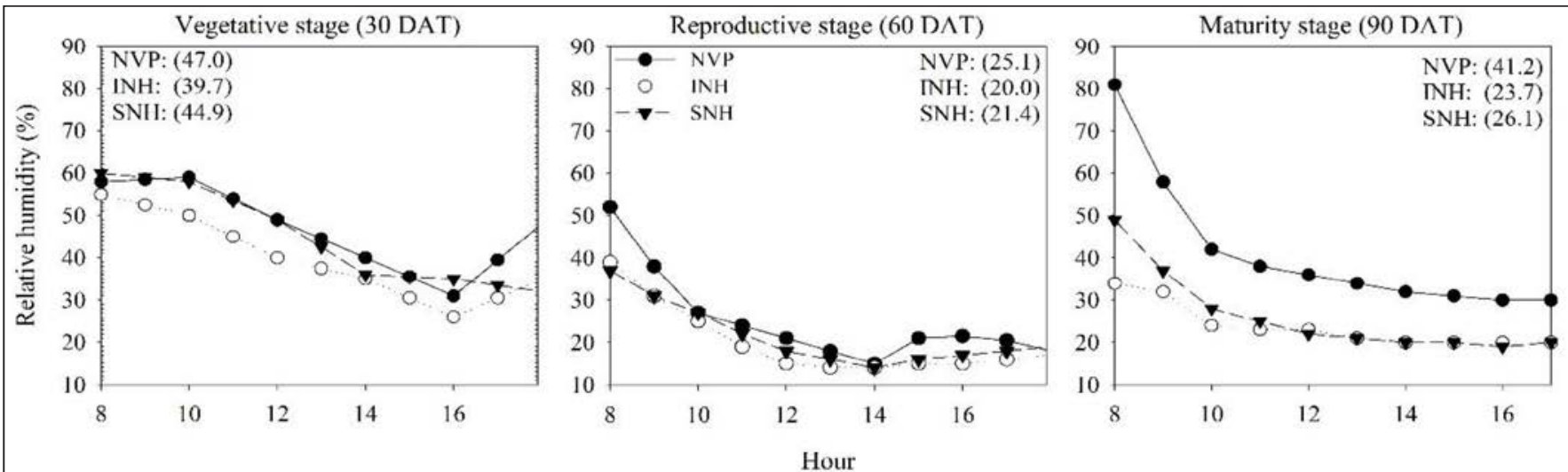

Fig. 4: Relative humidity at hourly interval under protected structures at different growth stages
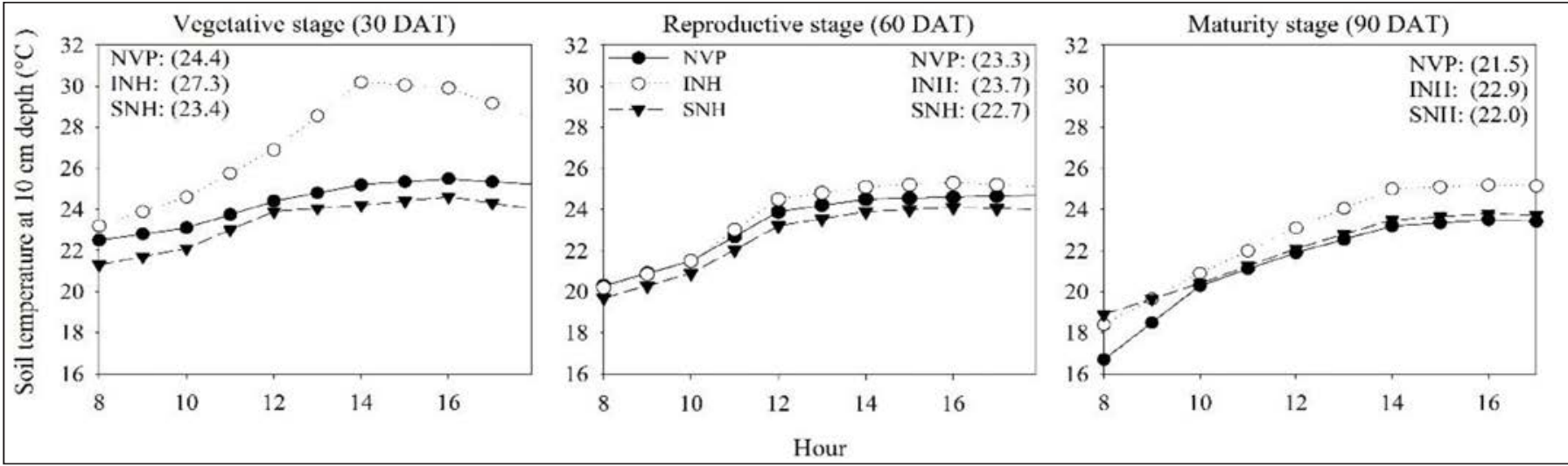

Fig. 5: Soil temperature at hourly interval under protected structures at different growth stages

conditions (Table 1 and Fig. 4) probably due to direct radiation cut and consequent decrease in air temperature. The range of hourly mean of relative humidity was 20-47 per cent across all crop stages in the protected structure (Fig.4). The relative humidity was 17 and 4 per cent higher in NVP and SNH, respectively as compared with INH. The higher RH inside the protected structures than open air was probably the result of water vapour being transpired by the crop and reduced mixing with drier air outside the cladded area. Among the structures, the RH was highest in NVP as compared to net houses because polyethylene film acts as a barrier to air movement. Additionally, high vapour production caused by high plant biomass (leaf area) could have resulted in high $\mathrm{RH}$ levels in NVP. The lowest RH in INH possibly due to high radiation and larger possibility of air mixing, and relatively less plant canopy (as evident from leaf area; Table 2).

\section{Soil temperature}

The higher soil temperature impedes root development activity and affects crop growth and production. The range of hourly mean soil temperature at $10 \mathrm{~cm}$ depth during phenological stages in the structures was 20.0 to $27.3^{\circ} \mathrm{C}$ and it followed order of $\mathrm{INH}>$ $\mathrm{SNH}>\mathrm{NVP}$ at vegetative and reproductive stage, while at maturity stage it was almost similar for NVP and SNH which were lower than INH. (Fig. 5). In this study, mean soil temperature at $10 \mathrm{~cm}$ depth under all structures was lower as compared to ambient soil temperature (Table 1 and Fig. 5). Among the structures, the variation in temperature change throughout the day was lowest in NVP, while the highest was recorded in INH. Compared to the open field conditions, the soil temperature was consistently lower $\left(2.0-5.0^{\circ} \mathrm{C}\right)$ under polyhouses, irrespective of the crop growing periods (Job, 2017).

\section{Growth parameters}

The aerial dry biomass in NVP was 13 and 12 per cent higher over INH and SNH, respectively (Table 2). Similarly, the vine length, stem girth and node number per plant was 54 and 15 per cent, 12 and 37 per cent and 12 and 13 per cent higher as compared to INH and $\mathrm{SNH}$, respectively. The highest biomass, vine length and 
node number in NVP was probably due to availability of PAR in optimum range, high $\mathrm{RH}$ and favourable range of air and soil temperature. Additionally, diffused PAR under NVP in contrast to direct radiation under INH and SNH gives boost to photosynthesis also. Low intensity and diffused light inside NVP may also be responsible for internodal elongation resulting in more vine length as reported by Dingal et al. (2018) in cucumber. It is believed that synthesis of auxin under low light intensity may also contribute towards internodal elongation (Smitha and Sunil, 2016). Further, at low soil temperature, the root development activity might lead to efficient acquisition of water and nutrients in NVP in contrast to INH and SNH. Also, relatively lower radiation intensity in polyhouse might have resulted in more leaf area (Table 3), thereby providing more photosynthetic area. On similar lines, Fan et al. (2013) reported a decrease in the specific leaf area in tomato crop due to higher radiation levels. In the present study too, it was observed in cucumber where leaf area was less under INH. Lower stem girth and dry biomass of plants in INH and SNH (Table 2) conclusively convey the shortcoming of these two structures.

\section{Physio-biochemcial parameters}

The chlorophyll content in NVP was 23 per cent higher compared to INH while there was no significant difference as compared to SNH (Table 3). Further, the Fv/Fm (indicating high PS II efficiency) was highest in order of NVP>SNH>INH (Table 3). The lower Fv/ Fm in INH reflected that cucumber plants were under stress in comparison to other structures probably due to higher radiation, and air and soil temperature. These two contributing parameters along with microclimatic variables under NVP led to highest net photosynthesis (Pn) and it was 24 and 60 per cent over INH and SNH, respectively (Table 3). Even though, there was no significant difference in leaf area and chlorophyll content in NVP and SNH, but the activity of Pn and Fv/Fm was apparently higher in NVP probably due to better diffused radiation from the cladding film concomitant with better microclimatic variables. All these factors accounted for more biomass accumulation in NVP.

\section{Yield and yield parameters}

The favourable microclimate variables like optimum radiation, low air and soil temperature and high humidity in NVP favourably influenced the cucumber plant growth and physiological process as reflected through high aerial biomass (Table 2) and subsequently the fruit yield. Yield per plant was highest in NVP and it was 42 and 142 per cent higher than in INH and SNH, respectively (Table 3 ). The yield variation between the two net houses was also very high. The high fruit yield in NVP over the net houses was attributed to higher fruit numbers and mean fruit weight which were 25 and 99 per cent and 14 and 23 per cent as compared to INH and SNH, respectively, between the net houses, INH produced higher yield than SNH. Rajkumar et al. (2002) in tea ascribed high yield in polyhouse to decreased evapotranspiration followed by increased stomatal conductance and subsequent increase in $\mathrm{CO}_{2}$ assimilation and this may hold valid in the present study too.

\section{CONCLUSION}

The results of study revealed that naturally ventilated polyhouse structure modified microenvironment to great extent by reducing PAR (70\%), net radiation (48\%) and air temperature $1.2^{\circ} \mathrm{C}$ while increased relative humidity by 17 per cent followed by shade net and insect proof net house. This creates a favorable environment for growth and development, and physiological functioning of cucumber plants inside NVP as compared to other structures in the hot arid ecosystem. Therefore, it can be recommended that among the low-tech protected structures, naturally ventilated polyhouse is the best low-tech protected structure to provide more favorable microclimate for cucumber cultivation in the hot arid climate.

\section{ACKNOWLEDGEMENT}

The authors are grateful to the Director, ICAR-CAZRI, Jodhpur for extending help and support in carrying out this study.

Conflict of Interest Statement : The author(s)declare(s) that there is no conflict of interest.

Disclaimer : The contents, opinions, and views expressed in the research article published in the Journal of Agrometeorology are the views of the authors and do not necessarily reflect the views of the organizations they belong to.

Publisher's Note : The periodical remains neutral with regard to jurisdictional claims in published maps and institutional affiliations. 


\section{REFERENCES}

Arnon, D., (1949). Copper enzymes in isolated chloroplasts. Polyphenoloxidase in Beta vulgaris. Plant Physiol., 24(1): 1-15.

Dingal D.K., Patil, S.S., Birada, M.S, Mantur, S.M., (2018). Influence of different protected conditions on growth and yield of parthenocarpic cucumber (Cucumis sativus) hybrids. Int. J. Curr. Microbiol. Appl. Sci., 7(5): 1619-1624

Fan, X.X., Xu, Z.G., Liu, X.Y., Tang, C.M., Wang, L.W. and Han, X.L., (2013). Effects of light intensity on the growth and leaf development of young tomato plants grown under a combination of red and blue light. Sci. Hort., 153:50-55.

Job M., (2017). Study on changes in microclimatic parameters under poly-house with different color plastic mulching during tomato cultivation. $J$. Pharmacogn. Phytochem., 7(1S): 689-694.

Kumar, P., Khapte, P. S., Saxena, A. and Kumar P., (2019). Evaluation of gynoecious cucumber (Cucumis sativus) hybrids for early-summer greenhouse production in western Indian arid plains. Indian J. Agri. Sci., 89 (3): 545-50.

Mahmood, A., Hu, Y., Tanny, J. and Asante, E.A., (2018). Effects of shading and insect-proof screens on crop microclimate and production: A review of recent advances. Sci. Hort., 241:241-251.

Rajasekharan, G. and Nandini, K., (2015). Photosynthetic characters in relation to yield of cucumber grown in naturally ventilated polyhouse. J. Trop. Agric. 53(2): 200-205.
Rajkumar, R., Marimuthu, S., Muraleedharan, N., (2002). Photosynthetic efficiency of sun and shade grown tea plants. Sri Lanka J. Tea Sci., 67: $67-75$.

Samanta, M, Hazra, P., (2019). Microclimate suitability for green and coloured sweet pepper hybrids in open and protected structures in sub-tropical humid climate of West Bengal. J. Agrometeorol., 21(1): 12-17.

Shukla, C., Bhakar, S.R., Lakhawat, S.S., (2016). Development of the crop coefficient for capsicum (Capsicum annum L.) under protected structures. J. Agrometeorol., 18(2): 258-260.

Singh M C, Singh, J. P., Singh, K. G., (2017). Optimal operating microclimatic conditions for drip fertigated cucumbers in soilless media under a naturally ventilated greenhouse. Indian J. Ecol., 44, 821-826.

Smitha K., Sunil K.M., (2016). Influence of growing environment on growth characters of cucumber (Cucumis sativus). J. Trop. Agric., 54(2): 201203.

Sudhakar, K., Srivastava, T., Satpathy, G. and Premalatha, M., (2013). Modelling and estimation of photosynthetically active incident radiation based on global irradiance in Indian latitudes. Int. J. Energy Environ. Eng., 4(1), p.21. 